\title{
An Empirical Analysis of Management Challenges in Service Factories, Service Shops, Mass Services and Professional Services
}

\author{
Rohit Verma \\ Department of Management, DePaul University, Chicago, Illinois, USA
}

This study presents an empirical snapshot of management challenges among different types of service industries (Service Factory, Service Shop, Mass Service, and Professional Service). Based on data collected (sample size $=273$; response rate 97.5 percent) from the managers of four services (Fast Food, Auto Repair, Retail Sales, Legal Services) we show how management challenges change with customer contact/customization and labour intensity. These results have important implications for understanding "real life" service operations, for process improvement, and for service design.

\section{Introduction}

As the post-industrial economy evolves, the service sector continues to increase in importance, both in terms of its contribution to the gross domestic product (GDP) of all advanced economies and in terms of the percentage of workforce employed in services. Accordingly, the last decade has witnessed an increased emphasis on teaching and research on service management issues by business schools and professional organizations (Chase, 1996; Roth et al., 1997; Voss and Johnston, 1995). In response, numerous articles have appeared in both academic and practitioner-based publications which provide guidelines for effective management in services (for example, Chase and Hayes, 1991, Karmarker and Pitbladdo, 1995; Lovelock, 1993). Several other articles present typologies/taxonomies and provide generalized frameworks for analyzing service operations (for example, Chase, 1981; Kellogg and Nie, 1995; Schmenner, 1986; Silvestro et al., 1992; Wemmerlov, 1990). Most of the published frameworks classify different service industries in two-four categories and provide directions for improving quality, productivity and operating efficiency.

Recent articles argue that service management research has moved beyond the classification stage and therefore now it is necessary to validate the proposed service management concepts and frameworks (Chase, 1996; Flynn et al., 1990; Meredith et al., 1989; Swamidass, 1991). Even though service classification frameworks continue to evolve during the 1990s (for example - Wemmerlov, 1990; Silvestro et al., 1992; Kellog and Nie, 1995) there is 
now an increased interest in empirically testing theoretical concepts proposed earlier. For example, recently Kellogg and Chase (1995) empirically identified the three dimensions of customer contact: contact time, intimacy, and, information. Similarly Silvestro, Fitzgerald, Johnston and Ross (1992) gathered in-depth data from eleven service organizations and identified the people-focused, people/equipment-focused and equipment-focused firms. More recently, teams of international researchers have started collecting large scale empirical data from senior executives from service firms in Europe and the USA (Roth et al., 1997; Voss and Johnston, 1995).

This paper presents an empirical snapshot of the management challenges experienced by the managers in four different types of services (classified by Schmenner, 1986): the service factory (SF), the service shop (SS) the mass service (MS) and, the professional service (PS). Since the publication of Schmenner's (1986) article, several introductory operations and service management textbooks have included the service process matrix (SPM) as a framework for analyzing service operations (for example, Fitsimmons and Fitsimmons, 1997). SPM has also been cited in research articles as the basis for comparison and/or developing a new framework for services (for example, Chase, 1996; Kellogg and Nie, 1995; Wemmerlov, 1990). In fact, it will not be an exaggeration to say that a majority of the service management community regards SPM as the primary service classification scheme (similar to Hayes and Wheelwright's (1984) Product-Process Matrix for manufacturing operations).

We gathered data relating to management challenges experienced by managers of four industries (fastfood, auto repair, retail sales and legal services) representing SF, SS, MS, and PS classifications (Schmenner, 1986). These services were chosen because they differ in terms of various attributes of service delivery systems as suggested by the SPM. Based on empirical data collected from 273 managers, we show how certain management challenges differ across four types of services. We believe that the results provide valuable insight into the understanding of service processes and also provide directions for service process improvement.

We choose Schmenner's (1986) SPM framework as a basis for our study for several reasons. First, SPM classifies services based on the three dimensions commonly associated with service operations: customer contact, customization and labour intensity. Second, SPM provides a detailed and comprehensive list of management challenges associated with different types of service operations. And third, the SPM framework expands Chase's $(1978,1981)$ customer-contact approach that has received wide citation in both academic and practitioner literature related to service management.

\section{Service Typologies/Taxonomies: A Review}

The diversity of the service sector makes it difficult to make useful generalizations concerning the management of service organizations. Therefore, a considerable amount of research has been focused on developing service classification schemes. For example, Judd (1964) classified services according to three categories: rented goods, owned goods and non- 
goods services. Similarly, Rathmell (1974) categorized services according to: type of buyer, buyer motives, buying practices, type of seller, and degree of regulation. Even though these classifications show how some services are different from the others, they do not provide much useful insight into the design and management of service processes from an operational perspective.

More recent classification schemes (Table I) have explored the complex nature of service delivery systems with the goal of identifying differentiating characteristics, which affect quality and process improvement, as well as service design. For example, Shostack (1977) and Sasser et al. (1978) developed the concept of a "product-service package" based on the tangible versus intangible nature of services. Based on similar ideas, Levitt $(1972,1976)$ suggested that services are commonly thought of in humanistic terms and manufacturing is thought of in technocratic terms. Accordingly, manufacturing is viewed as efficient and forward-looking, whereas services are viewed as primitive and inefficient. In order to remedy this pervasive yet inaccurate assessment, Levitt suggested that services should be viewed as a type of manufacturing or production line.

More recent researchers believe in an integrated approach to service management. Thomas (1978) argues that a large part of manufacturing experience is irrelevant to the management of service operations because services are very different from manufacturing. Sullivan (1981) and Bowen and Cummings (1990) also advocate an integrated approach to service management and suggest that operations management researchers must include organizational behavior and marketing constructs and techniques to address service operations problems adequately.

In addition to the above-cited studies, a number of articles and books emphasize the multifunctional nature of services. Therefore, recent service classification schemes build on managerially useful service delivery system attributes. For example, Lovelock (1983) classifies services in five different two-by-two matrices and examines how the specific nature of services in a particular class affects operations and marketing. Lovelock's (1983) framework addresses the following questions:

(1) What is the nature of the service act?

(2) What type of relationship does the service organization have with its customers?

(3) How much room is there for customization and judgment on the part of the service provider?

(4) What is the nature of demand and supply for the service?

(5) How is the service delivered?

Lovelock (1983) proposed that his classification scheme addressing the above five questions can help managers develop a better understanding of their business.

Chase $(1978,1981)$ proposed that if there is less direct customer contact in the service system, then the service system is more likely to operate at its peak efficiency. Conversely, the 


\begin{tabular}{|c|c|}
\hline Author(s) & Categories/groups \\
\hline Judd (1964) & $\begin{array}{l}\text { Rented goods services } \\
\text { Owned goods services } \\
\text { Non-goods services }\end{array}$ \\
\hline Rathmal (1974) & $\begin{array}{l}\text { Types of seller } \\
\text { Types of buyer } \\
\text { Buying motives } \\
\text { Buying practice } \\
\text { Degree of regulation }\end{array}$ \\
\hline $\begin{array}{l}\text { Shostack (1977) } \\
\text { Sasser, Olsen and Woyckoff (1978) }\end{array}$ & $\begin{array}{l}\text { Proportion of physical goods and intangible services } \\
\text { contained in each "product-service package" }\end{array}$ \\
\hline Chase $(1978,1981)$ & $\begin{array}{l}\text { Services affecting people vs those affecting goods } \\
\text { Permanent vs temporary effects of service } \\
\text { Physical vs mental effects of service } \\
\text { Individual vs collective services } \\
\text { Degree of customer contact }\end{array}$ \\
\hline Kotler (1980) & $\begin{array}{l}\text { People vs equipment based } \\
\text { Extent of customers' presence } \\
\text { Public - private vs for-profit - non-profit }\end{array}$ \\
\hline Lovelock (1983) & $\begin{array}{l}\text { Five two-by-two classification matrices based on the } \\
\text { following ideas: } \\
\text { Nature of service act } \\
\text { Relationship between service provider and customer } \\
\text { Customization } \\
\text { Demand and supply } \\
\text { Service delivery }\end{array}$ \\
\hline Schmenner (1986) & $\begin{array}{l}\text { Service process matrix based on two dimensions: } \\
\text { Customer contact and customization } \\
\text { Labour intensity }\end{array}$ \\
\hline Mersha (1990) & $\begin{array}{l}\text { Degree of customer contact. Definition of customer } \\
\text { contact expanded to include active and passive } \\
\text { contact }\end{array}$ \\
\hline Wemmerlov (1990) & $\begin{array}{l}\text { Two-dimensional matrix based on "rigid" vs "fluid" } \\
\text { service processes and degree of customer contact }\end{array}$ \\
\hline Chase and Hayes (1991) & Based on competitive stage \\
\hline $\begin{array}{l}\text { Slivestro, Fitgerald, Johnston and } \\
\text { Voss (1992) }\end{array}$ & $\begin{array}{l}\text { Two-dimensional classification matrix based on } \\
\text { "rigid" vs "fluid" service process and degree of } \\
\text { customer contact }\end{array}$ \\
\hline Kellog and Nie (1995) & $\begin{array}{l}\text { Two-dimensional classification matrix based on } \\
\text { service process structure and service package } \\
\text { structure }\end{array}$ \\
\hline Roth, Chase and Voss (1997) & $\begin{array}{l}\text { Two-dimensional classification matrix based on } \\
\text { service practice and performance index }\end{array}$ \\
\hline
\end{tabular}

Table I. Service typologies/taxonomies 
system is less likely to operate at its peak potential with high direct customer contact. Mersha (1990) proposed a broadened definition of customer contact and differentiated between active and passive contact. Based on these distinctions, Mersha (1990) extended the customer contact model and addressed several earlier concerns about this classification scheme. Building on the customer contact approach to services, Schmenner (1986) proposed the Service Process Matrix (SPM), based on three characteristics of service delivery systems. The SPM expands the customer contact model and categorizes services on two dimensions: labour intensity; and customer contact and service customization. More recently, Wemmerlov (1990) proposed a classification of service processes that included degree of customer contact, complexity and divergence and Kellogg and Nie (1995) proposed a two-dimensional matrix which connected the characteristics of service-products with service-processes.

The single common characteristic of all the cited studies is that they are primarily conceptual or theoretical in nature. Each of the cited studies presents a typology of either ideal service management or theoretically derived differences between services. As a result, each of the studies provides important insights into important characteristics of services. Yet, many of these studies are based on anecdotal or actual experience with a representative sample of companies, and none has been empirically validated using a broad sample of quantitative data. For example, even though North American Industry Classification System (NAICS) realizes the difficulties in classifying services, it is still proposing that production processes-based classification scheme should be used in service operations (US Department of Commerce, 1994). Our research is an attempt to empirically explore different aspects of one widely used service classification scheme: the service process matrix.

During the recent years service taxonomies based on empirical research have started to appear in academic literature. For example, based on in-depth data on six distinguishing categories (equipment/people focus, customer contact time/transaction, degree of customization, degree of discretion, value added back office/front office, and product/process focus) collected from 11 different service industries Silvestro et al. (1992) developed a two-bytwo classification scheme. Their two axes represent number of customers processed by a typical service unit/day and people/equipment focus. They observed that the service industries follow the diagonal from people focus-low customers top-left corner (professional service) to center representing medium people/equipment focus-medium number of customers (service shop) to right-down corner equipment focus-high customers (mass service) (note that the names of different service groups are similar to Kellogg and Nie (1995) and Schmenner (1986) however the definitions are not necessarily the same). In another series of studies, teams of international researchers have been collecting empirical data related to managerial practices and performance from a large number of service industries in Europe and North America (Chase and Voss, 1997; Voss and Johnston, 1995). Our study, although not as elaborate, is also an attempt to study some unique characteristics of service industries using empirical data. 


\section{Service Process Matrix: A Review and Hypothesis Development}

Schmenner (1986) proposed the service process matrix (SPM), based on three characteristics of service delivery systems: labour intensity; customer contact; and service customization. Labour intensity is defined as the ratio of the labour cost incurred to the value of the plant and equipment. A high labour intensity business involves relatively small plant and equipment investment and a considerably higher investment of worker time, effort, and cost. The second dimension of SPM combines the other two distinct concepts: customer contact and customization. A service with a high level of contact is one in which the customer can actively intervene in the service process. A service with high customization aims at satisfying an individual's particular preferences. The joint measure (customer contact/customization) has a high value when a service exhibits both a high level of contact and a high level of customization for the customers. Schmenner's (1986) two-by-two SPM classifies services as service factory, service shop, mass service, and professional service. Figure 1 shows SPM and the corresponding management challenges associated with each type of service (reproduced from Schmenner (1986)). For example, management challenges for services with low labour intensity (service factory and service shop) include capital decisions, technological advances, etc. A brief description of each of the four service types is provided below:

- Service factory. Services with both low customer contact/customization and a low degree of labour intensity are classified as service factories. Analogous to assembly

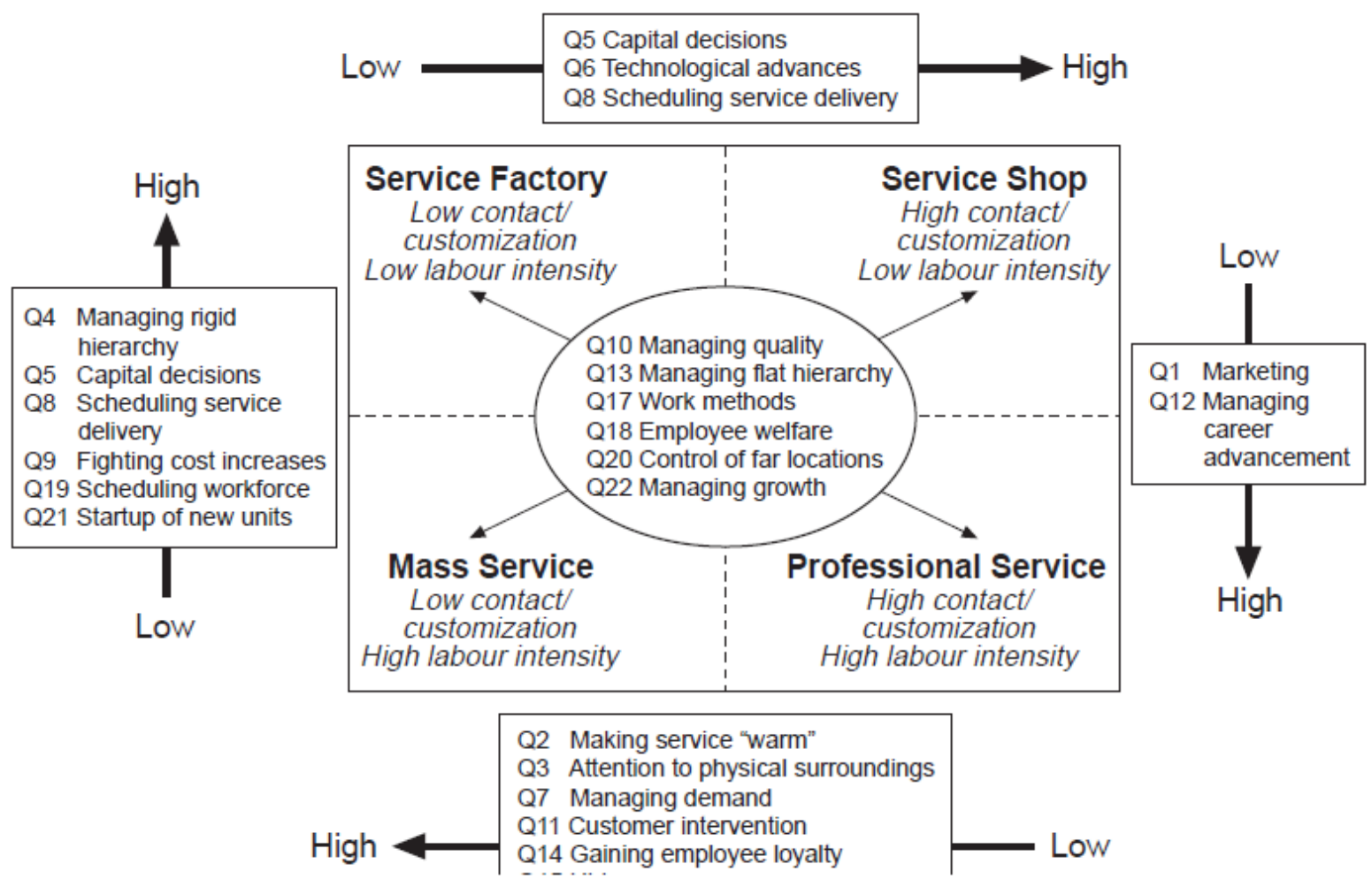

Figure 1. Service process matrix 
line type processes in manufacturing, the facilities and equipment account for a large fraction of costs. Much of the transportation industry (airlines, trucking companies), hotels and fastfood establishments can be classified as Service Factories.

- Service shop. Services with low labour intensity but high customer contact/customization are classified as service shops. Similar to a jobshop type of operation in manufacturing, a Service Shop can provide varied customized services for its customers. Hospitals, auto and other repair services are some examples of Service Shops.

- Mass service. Mass services are characterized by high labour intensity in combination with low customer contact/customization. Retail companies, wholesalers and schools are examples of mass service.

- Professional service. These services involve high customer contact/customization as well as a high degree of labour intensity. Services provided by doctors, lawyers, accountants and architects have very high labour costs due to the large amount of expertise/specialization associated with these professions. In addition, these services tend to be highly customized according to the particular situation/need of each customer.

Therefore, building on SPM (Figure 1) several directional relationships between service dimensions (labour intensity, customer contact/customization) and management challenges can be proposed. For example, according to SPM "fighting cost increases" is an important challenge for service shops and professional services (both classified as high customer contact/customization services) and not an important challenge for service factories and mass services (low customer contact/customization). Hence it can be concluded that SPM proposes that cost-reduction becomes more of a management challenge as customer contact/customization increases. Similarimplicit proposed directional relationships could be identified for each of the 22 management challenges identified by SPM. Table II summarizes these hypothesized relationships based on SPM.

The objective of this study is to empirically test if the management challenges indeed differ across different types of services (service factory, service shop, mass service, and professional service) as proposed by SPM (see Table II). Specifically, we investigate the following three research questions:

(1) How do management challenges differ across various types of service industries with change in customer contact/customization?

(2) How do management challenges differ across various types of service industries with change in the degree of labour intensity?

(3) How are management challenges across various types of service industries affected by the interaction of customer contact/customization and labour intensity? 


\begin{tabular}{|c|c|c|c|}
\hline No & Management challenge & $\begin{array}{l}\text { Labour } \\
\text { intensity }\end{array}$ & $\begin{array}{l}\text { Customer } \\
\text { contact/ } \\
\text { customization }\end{array}$ \\
\hline Q1 & Marketing & & Negative \\
\hline Q2 & Making service "warm” & & Negative \\
\hline Q3 & Attention to physical surroundings & & Negative \\
\hline Q4 & $\begin{array}{l}\text { Managing fairly rigid hierarchy with need for standard } \\
\text { operating procedures }\end{array}$ & & Negative \\
\hline Q5 & Capital decision & Negative & \\
\hline Q6 & Technological advances & Negative & \\
\hline Q7 & Managing demand to avoid peak and to promote off-peaks & Negative & \\
\hline Q8 & Scheduling service delivery & Negative & \\
\hline Q9 & Fighting cost increase & & Positive \\
\hline Q10 & Maintaining quality & & Positive \\
\hline Q11 & Reacting to customer intervention in process & & Positive \\
\hline Q12 & Managing advancement of people delivering service & & Positive \\
\hline Q13 & $\begin{array}{l}\text { Managing flat hierarchy with loose subordinate-superior } \\
\text { relationships }\end{array}$ & & Positive \\
\hline Q14 & Gaining employee loyalty & & Positive \\
\hline Q15 & Hiring & Positive & \\
\hline Q16 & Training & Positive & \\
\hline Q17 & Work methods development and control & Positive & \\
\hline Q18 & Employee welfare & Positive & \\
\hline Q19 & Scheduling workforces & Positive & \\
\hline Q20 & Control of far-flung geographical locations & Positive & \\
\hline Q21 & Startup of new units & Positive & \\
\hline Q22 & Managing growth & Positive & \\
\hline
\end{tabular}

Table II. Proposed relationships between management challenges and service classification dimensions.

\section{Research Methods}

The data for this study were collected from service managers in four different types of industries: fast food (service factory), automobile repair (service shop), retail sales (mass service) and legal services (professional service). A random sample of 70 firms from each of these industries was selected from the yellow pages phone directory of a large metropolitan area in the western USA. Even though a number of national chains (e.g. McDonalds, Taco Bell, Sears Auto Center, J.C. Penny etc.) own/operate multiple service facilities in this metropolitan area, we only contacted at the most three service-location managers of each chain.

The manager of each service firm received a cover letter from the lead researcher, a forwarding letter from the chairperson of the management department of the sponsoring university and a two-page questionnaire. The questionnaire asked the managers to rate 22 management challenges (identified by Schmenner, 1986) on a five point Likert-type scale ( $1=$ not a challenge; 3 = average challenge; 5 = big challenge). The items addressing management challenges included in the questionnaire are shown in Table II and Figure 1. In addition, the instrument contained four demographic questions regarding the gender, age, work experience and education level of the respondent. The length of the questionnaire was intentionally kept to less than two pages so that the total time needed to respond to the survey was less than 15 
minutes. We offered to send a summary of the results to the managers and provided an opportunity to participate in a raffle and win a $\$ 200$ cash prize to encourage participation in the data collection effort (Linsky, 1976).

The survey instrument was hand delivered to the managers of each of the 280 service firms sampled. The managers were requested to complete the questionnaire immediately (if possible) and told that it would take less than 15 minutes of their time. Almost 75 percent of the managers completed the questionnaire immediately. The rest of the managers agreed to complete the survey within a week. A return visit was made to these companies after 4-8 days with another copy of the survey instrument. Only six firms chose not to participate in the study. One questionnaire was not complete and was therefore excluded from further analysis. The resulting final sample size was 273 , or an effective response rate of 97.5 percent.

$\underline{\text { Results }}$

Table III contains the demographic information about the respondents. The difference in education level of the respondents can be clearly seen in Table III. The managers of legal services were most highly educated with approximately 95 percent with college degrees. Approximately 40 percent of the managers in retail sales had a college degree. On the other hand, less than 20 percent of the managers in the fast food and automobile repair industries had college degrees. Another interesting demographic pattern was observed with respect to the gender of the respondents \pm there were no female respondents from the auto repair industry and there were only 7.25 percent female respondents from legal services. The maximum number of female respondents (39 percent) was from the retail sales followed by 29 percent respondents from the fast food industry. Table III also shows the average ages, average

\begin{tabular}{lcccc}
\hline & $\begin{array}{c}\text { Fast food } \\
\text { (service } \\
\text { factory) }\end{array}$ & $\begin{array}{c}\text { Automobile } \\
\text { repair } \\
\text { (service shop) }\end{array}$ & $\begin{array}{c}\text { Retail sales } \\
\text { (mass service) }\end{array}$ & $\begin{array}{c}\text { Legal } \\
\text { (profices } \\
\text { servional }\end{array}$ \\
\hline Education (percent) & & & & \\
High school & 48.48 & 39.39 & 26.09 & 0.00 \\
Associate degree/some college & 36.36 & 40.91 & 34.78 & 4.35 \\
Four year college degree & 13.64 & 19.70 & 28.99 & 4.35 \\
Masters & 1.52 & 0 & 10.14 & 31.88 \\
Doctorate & 0 & 0 & 0 & 58.42 \\
Female respondents (percent) & 28.79 & 0.00 & 39.13 & 7.25 \\
Average age (years) & 28.23 & 38.70 & 31.26 & 44.54 \\
Average work experience (years) & 6.82 & 18.50 & 9.75 & 17.84 \\
Sample size & 66 & 69 & 69 & 69 \\
\hline
\end{tabular}

Table III. Demographics 
work experience and the sample sizes for the four industries.

The average scores for the 22 management challenges for the four industries are presented in Table IV. It can be clearly seen that none of the items are equally important for all the industries. Table IV is not based on any statistical test and therefore should only be used to "take a first look" at the empirical results.

Maintaining quality of service (Q10) was found to be the top management challenge for all four industries followed by employee hiring (Q15) and training (Q16). In fact, quality (Q10) and training (Q16) are among top-three management challenges for managers in all four

\begin{tabular}{|c|c|c|c|c|c|c|}
\hline No & Management challenge & All & $\mathrm{SF}$ & SS & MS & PS \\
\hline Q1 & Marketing & 3.13 & 2.94 & 3.00 & 3.48 & 3.10 \\
\hline Q2 & Making service "warm" & $\begin{array}{l}3.73 \\
(4)\end{array}$ & $\begin{array}{c}3.92 \\
(4)\end{array}$ & 3.55 & $\begin{array}{l}3.88 \\
(4)\end{array}$ & $\begin{array}{l}3.58 \\
(2)\end{array}$ \\
\hline Q3 & Attention to physical surroundings & 3.17 & 3.36 & 2.85 & 3.51 & 2.94 \\
\hline Q4 & $\begin{array}{l}\text { Managing fairly rigid hierarchy with need for standard } \\
\text { operating procedures }\end{array}$ & 2.88 & 3.09 & 2.94 & 2.81 & 2.68 \\
\hline Q5 & Capital decisions & 2.96 & 2.55 & 3.71 & 2.62 & 2.96 \\
\hline Q6 & Technology advances & 3.10 & 2.53 & $\begin{array}{l}3.88 \\
(2)\end{array}$ & 2.72 & 3.28 \\
\hline Q7 & $\begin{array}{l}\text { Managing demand to avoid peak and to promote } \\
\text { off-peaks }\end{array}$ & 3.20 & 3.15 & 3.18 & 3.51 & 2.96 \\
\hline Q8 & Scheduling service delivery & 2.84 & 2.58 & 3.41 & 2.55 & 2.83 \\
\hline Q9 & Fighting cost increase & 3.46 & 3.42 & $\begin{array}{l}3.80 \\
(4)\end{array}$ & 3.52 & 3.09 \\
\hline Q10 & Maintaining quality & $\begin{array}{l}4.03 \\
(1)\end{array}$ & $\begin{array}{c}3.94 \\
(2)\end{array}$ & $\begin{array}{l}4.06 \\
(1)\end{array}$ & $\begin{array}{c}4.10 \\
(2)\end{array}$ & $\begin{array}{l}4.03 \\
(1)\end{array}$ \\
\hline Q11 & Reacting to customer intervention in process & 3.25 & 3.20 & 3.27 & 3.61 & 2.91 \\
\hline $\begin{array}{l}\text { Q12 } \\
\text { Q13 }\end{array}$ & $\begin{array}{l}\text { Managing advancement of people delivering service } \\
\text { Managing flat hierarchy with loose subordinate-superi }\end{array}$ & 2.89 & 2.71 & 2.67 & 3.13 & 3.04 \\
\hline & relationships & 2.93 & 3.00 & 2.74 & 3.01 & 2.97 \\
\hline Q14 & Gaining employee loyalty & 3.46 & $\begin{array}{c}3.91 \\
(5)\end{array}$ & 3.30 & $\begin{array}{c}3.61 \\
(5)\end{array}$ & 3.04 \\
\hline Q15 & Hiring & $\begin{array}{l}3.81 \\
(2)\end{array}$ & $\begin{array}{l}4.06 \\
(1)\end{array}$ & 3.61 & $\begin{array}{r}4.17 \\
(1)\end{array}$ & $\begin{array}{l}3.41 \\
(3)\end{array}$ \\
\hline Q16 & Training & $\begin{array}{l}3.76 \\
(3)\end{array}$ & $\begin{array}{c}3.94 \\
(3)\end{array}$ & $\begin{array}{c}3.82 \\
(3)\end{array}$ & $\begin{array}{c}3.99 \\
(3)\end{array}$ & $\begin{array}{l}3.29 \\
(5)\end{array}$ \\
\hline Q17 & Work methods development and control & $\begin{array}{l}3.48 \\
(5)\end{array}$ & 3.42 & $\begin{array}{c}3.76 \\
(5)\end{array}$ & 3.36 & $\begin{array}{l}3.39 \\
\text { (4) }\end{array}$ \\
\hline Q18 & Employee welfare & 3.20 & 3.20 & 3.23 & 3.20 & 3.19 \\
\hline Q19 & Scheduling workforces & 3.12 & 3.53 & 3.02 & 3.49 & 2.45 \\
\hline Q20 & Control of far-flung geographical locations & 2.07 & 2.09 & 1.84 & 2.09 & 2.26 \\
\hline Q21 & Startup of new units & 2.50 & 2.77 & 2.59 & 2.87 & 1.78 \\
\hline Q22 & Managing growth & 3.20 & 3.08 & 3.26 & 3.35 & 3.10 \\
\hline
\end{tabular}

Notes:

a Top five management challenges within category

$\mathrm{SF}=$ Service factory; $\mathrm{SS}=$ Service shop; $\mathrm{MS}=$ Mass service; $\mathrm{PS}=$ Professional service 
industries. Employee hiring (Q17) and making service "warm" (Q2) were among top-five challenges for all industries except the service shops (auto repair). The managers in the two industries with low labour intensity and low customer contact/customization (fast food and retail sales) rated employee loyalty (Q14) as one of the top-five challenges. On the other hand, work and control methods (Q17) was found to be among top-five challenges for the two industries with high customer contact/customization.

To statistically test if indeed the management challenges are different for the four service industries, we conducted ordinary least square linear regressions with management challenges as dependent variable and two dummy independent variables ( $\mathrm{X} 1$ and $\mathrm{X} 2$ ) representing the four types of industry (statistically equivalent to t-tests or one-way ANOVA). Variable X1 represents the degree of labour intensity ( $\pm 1=$ low; $1=$ high) and $X 2$ represents the degree of customer contact/customization ( $\pm 1=$ low; 1 = high). Therefore a statistically significant b coefficients for the two variables would mean that the corresponding dependent variable (management challenges) are dependent on the degree of customer contact/customization and/or the degree of labour intensity.

Table $\mathrm{V}$ presents the $\mathrm{b}$ coefficients (statistically significant at $\mathrm{a}=0.05$ ) and statistical power for each coefficients. It can be clearly seen that several management challenges are impacted by the nature of the service processes. Both b coefficients (for customization/customer contact, and labour intensity) are statistically significant for only four variables (Q5, Q8, Q19, Q21). At least one of the two b coefficients for the total of 16 management challenges were found to be statistically significant at $a=0.05$. Neither of the two regression coefficients is significant for six management challenges (Q10, Q13, Q17, Q18, Q20 and Q22). In other words, quality, managing flat hierarchy, work methods, employee welfare, control of far-flung geographical locations, and managing growth are perceived as equally important challenges for all four industries.

Following Verma and Goodale's (1995) recommendation, we also calculated statistical power for all the significant b coefficients. The statistical power analysis results presented in Table $V$ show that 15 out of 20 statistically significant relationships have power over 0.6 (statistical power represents the probability of getting the same results in hypothesis testing if the same empirical study is repeated under similar environments). Statistical power for ten tests were found to be over 0.8 which is a sign of very strong relationship between the service classification dimension (labour intensity or customer contact/customization) and corresponding management challenge (Verma and Goodale, 1995).

Figure 2 summarizes the numerical results presented in Table $V$ and shows the directional influence of industry type on the different types of service processes. The arrows show the direction (positive vs negative) of the statistically significant $(a=0.05)$ relationships. The five management challenges not affected either by labour intensity or by customer contact/ customization are shown in the center. 
Customer contact/

\begin{tabular}{|c|c|c|c|}
\hline No & Dependent variable & Labour intensity $\left(\mathrm{X}_{1}\right)$ & customization $\left(\mathrm{X}_{2}\right)$ \\
\hline Q1 & Marketing & $0.1608(0.6177)$ & - \\
\hline Q2 & Making service "warm" & - & $-0.1724(0.7332)$ \\
\hline Q3 & Attention to physical surroundings & - & $-0.2622(0.9522)$ \\
\hline Q4 & $\begin{array}{l}\text { Managing fairly rigid hierarchy with need } \\
\text { for standard operating procedures }\end{array}$ & $-0.1339(0.5011)$ & - \\
\hline Q5 & Capital decisions & $-0.1723(0.7146)$ & $0.3714(0.9998)$ \\
\hline Q6 & Technological advances & - & $0.4719(1.0000)$ \\
\hline Q7 & $\begin{array}{l}\text { Managing demand to avoid peak and to } \\
\text { promote off-peaks }\end{array}$ & - & $-0.1321(0.9330)$ \\
\hline Q8 & Scheduling service delivery & $-0.1540(0.5150)$ & $0.2666(0.9330)$ \\
\hline Q9 & Fighting cost increases & $-0.1544(0.6150)$ & - \\
\hline Q10 & Maintaining quality & - & - \\
\hline Q11 & $\begin{array}{l}\text { Reacting to customer intervention in } \\
\text { process }\end{array}$ & - & $-0.1575(0.6107)$ \\
\hline Q12 & $\begin{array}{l}\text { Managing advancement of people delivering } \\
\text { service }\end{array}$ & $0.1991(0.8707)$ & - \\
\hline Q13 & $\begin{array}{l}\text { Managing flat hierarchy with loose } \\
\text { subordinate-superior relationships }\end{array}$ & (0.100) & - \\
\hline Q14 & Gaining employee loyalty & - & $-0.3030(0.9877)$ \\
\hline Q15 & Hiring & - & $-0.3087(0.9966)$ \\
\hline Q16 & Training & - & $-0.2083(0.8838)$ \\
\hline Q17 & Work methods development and control & - & - \\
\hline Q18 & Employee welfare & - & - \\
\hline Q19 & Scheduling workforces & $-0.1478(0.5595)$ & $-0.3980(0.9999)$ \\
\hline Q20 & Control of far-flung geographical locations & - & - \\
\hline Q21 & Startup of new units & $-0.1753(0.5261)$ & $-0.3394(0.9752)$ \\
\hline Q22 & Managing growth & - & - \\
\hline
\end{tabular}

Notes:

Only statistically significant coefficients at $\alpha=0.05$ are shown

The numbers in brackets represent statistical power at $\alpha=0.05$ level

\section{Table V. Regression weights}

Table VI presents the summarized regression results when interaction between labour intensity and customer contact/customization $(X 1 * X 2)$ is included as an independent variable, in addition to $X 1$ and $X 2$. The results show statistically significant interaction effects $(a=0.05)$ for the following management challenges: capital decisions (Q5), technological advances (Q6), managing demand (Q7), fighting cost increases (Q9), customer intervention (Q11), training (Q16), and startup of new units (Q21). The numerical sign for each interaction affect was found to be negative.

\section{Discussion}

The objective of this research was to investigate how management challenges differ across four types of service industries (service factory, service shop, mass service, and professional service). Empirical data show that several of the management challenges proposed by service process matrix (SPM) are indeed different for service factory, service shop, mass service and professional service industries. The following sub-sections discuss the results in terms of the two constructs (customization/customer contact, and labour intensity) used to classify service industries in SPM. 


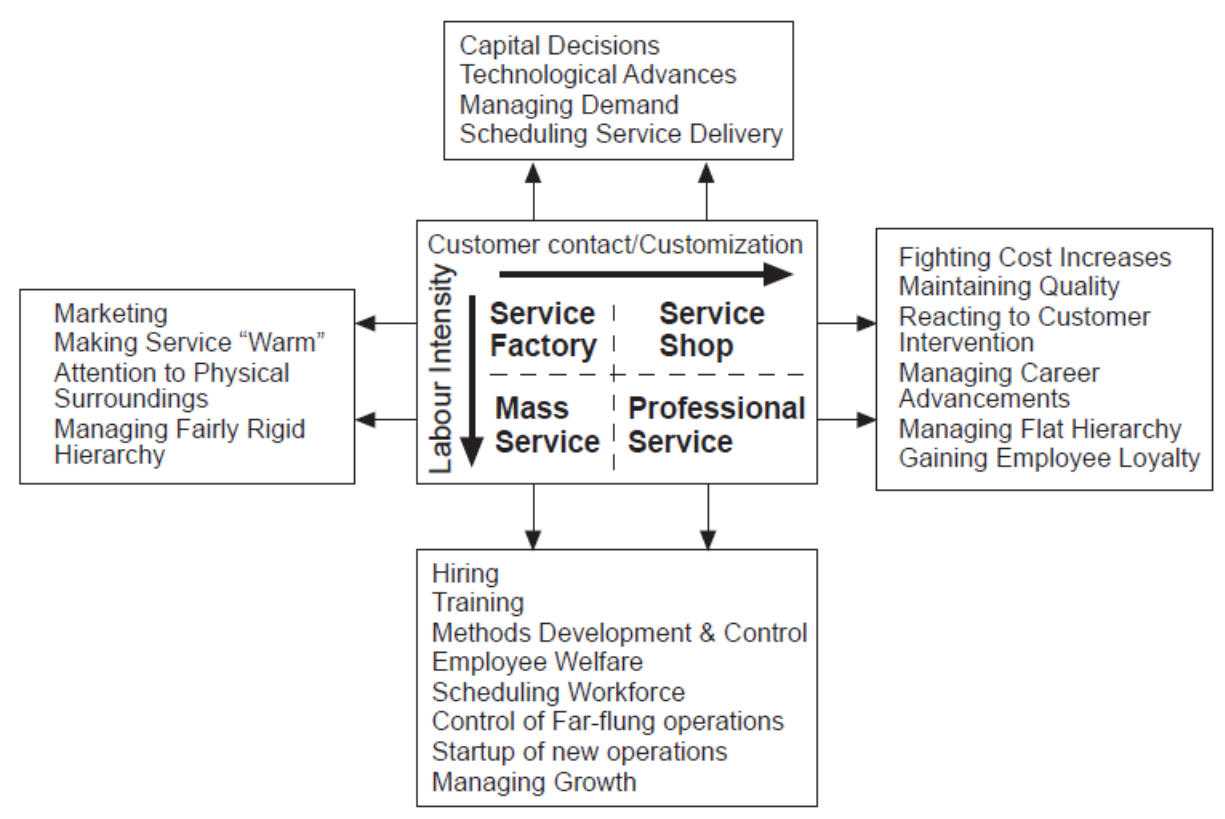

Figure 2. Observed management challenges relationships

\section{Impact of customization/customer contact}

The regression results (Table $V$ and Figure 2 ) show that capital decisions (Q5), technological advances (Q6), and scheduling service delivery $(\mathrm{Q} 8)$ are perceived to be more of a challenge with an increase in customer contact/customization. Results also show that a number of other management challenges $\left(Q_{2}, Q_{3}, Q 7, Q 11, Q 14, Q 15, Q 16, Q 19, Q 21\right)$ become less important as customer contact/customization increases.

The above empirical results make intuitive sense for most of the management challenges. For example both capital decisions and technological issues in the auto repair industry (service shop) can be expected to be more important than in fast food industry (service factory). Similarly, attention to physical surroundings, managing demand, making service "warm", and reacting to customer intervention can be expected to be more important for retail sales (mass service) and fast food (service factory) compared to auto repair. However it is not clear why employee related management challenges (hiring, training, scheduling, and loyalty) should be more important for low contact/customization services. Intuitively, these challenges should be important for both service shops and professional services (for example, employee hiring and training can be thought to be important for professional services).

\section{Impact of Labour Intensity}

The importance of managing career advancement of employees (Q12), and marketing (Q1) of services increases with labour intensity. However the results also show that several other management challenges are perceived to be more important in services with low labourintensity (see Figure 2). For example, the regression coefficients for capital decisions (Q5) and fighting cost increases (Q9) were found to be negative for $X 2$ which means that these 
challenges are more important for the service factory and service shops than for mass service and professional service. Similarly, starting new operations (Q21), workforce scheduling (Q19) and managing rigid organizational hierarchy (Q4) seem to be more important for service factory and service shops.

\begin{tabular}{|c|c|c|c|c|}
\hline No & Dependent variable & $\mathrm{X}_{1}$ & $\mathrm{X}_{2}$ & $\mathrm{X}_{1} * \mathrm{X}_{2}$ \\
\hline Q1 & Marketing & $0.1599(0.6151)$ & - & - \\
\hline Q2 & Making service "warm" & - & $-0.1728(0.7338)$ & - \\
\hline Q3 & $\begin{array}{l}\text { Attention to physical } \\
\text { surroundings }\end{array}$ & - & $-0.2617(0.9509)$ & - \\
\hline Q4 & $\begin{array}{l}\text { Managing fairly rigid hierarchy } \\
\text { with need for standard operating } \\
\text { procedures }\end{array}$ & $-0.1338(0.4994)$ & - & - \\
\hline Q5 & Capital decisions & $-0.1739(0.7365)$ & $0.3760(0.9999)$ & $-0.2094(0.8772)$ \\
\hline Q6 & Technological advances & - & $0.4764(1.0000)$ & $-0.2011(0.8850)$ \\
\hline Q7 & $\begin{array}{l}\text { Managing demand to avoid peak } \\
\text { and to promote off-peaks }\end{array}$ & - & - & $-0.1465(0.5999)$ \\
\hline Q8 & Scheduling service delivery & $-0.1551(0.5231)$ & $0.2696(0.9393)$ & - \\
\hline Q9 & Fighting cost increases & $-0.1559(0.6347)$ & - & $-0.1929(0.8135)$ \\
\hline Q10 & Maintaining quality & - & - & - \\
\hline Q11 & $\begin{array}{l}\text { Reacting to customer intervention } \\
\text { in process }\end{array}$ & - & $-0.1532(0.5975)$ & $-0.1946(0.8006)$ \\
\hline Q12 & $\begin{array}{l}\text { Managing advancement of people } \\
\text { delivering service }\end{array}$ & $0.1990(0.8693)$ & - & - \\
\hline Q13 & $\begin{array}{l}\text { Managing flat hierarchy with } \\
\text { loose subordinate-superior } \\
\text { relationships }\end{array}$ & - & - & - \\
\hline Q14 & Gaining employee loyalty & - & $-0.3034(0.9876)$ & - \\
\hline Q15 & Hiring & - & $-0.3070(0.9963)$ & - \\
\hline Q16 & Training & - & $-0.2051(0.8783)$ & $-0.1427(0.5851)$ \\
\hline Q17 & $\begin{array}{l}\text { Work methods development and } \\
\text { control }\end{array}$ & - & - & - \\
\hline Q18 & Employee welfare & - & - & - \\
\hline Q19 & Scheduling workforces & $-0.1488(0.5686)$ & $-0.3952(0.9999)$ & - \\
\hline Q20 & $\begin{array}{l}\text { Control of far-flung geographical } \\
\text { locations }\end{array}$ & - & - & - \\
\hline Q21 & Startup of new units & $-0.1769(0.5410)$ & $-0.3348(0.9740)$ & $-0.2087(0.6821)$ \\
\hline Q22 & Managing growth & - & - & - \\
\hline \multicolumn{5}{|c|}{$\begin{array}{l}\text { Notes: } \\
\text { Only statistically significant coefficients at } \alpha=0.05 \text { are shown } \\
\text { The numbers in brackets represent statistical power at } \alpha=0.05 \text { level }\end{array}$} \\
\hline
\end{tabular}

Table VI. Regression weights when two-way interaction between labour intensity and customer contact/customization is included as an independent variable

The directional relationships of management challenges with respect to labour intensity make intuitive sense. For example, it is understandable that the managers in fast food and auto repair industries consider workforce scheduling to be more important because of a relatively larger fraction of part-time employees working for these industries. Similarly competitive market pressure requires the above two industries to invest in new technologies and keep costs low. At the same time, because of highly educated employees it is a challenge to effectively manage career advancement of employees in professional services.

\section{Interaction of Customer Contact/Customization and Labour Intensity}

Schmenner (1986) suggested that the dynamic nature of service industry is forcing businesses to move up along the diagonal (professional service to service factory). The 
diagonals represent the direction of interaction among the two classification constructs of the SPM. Therefore we conducted the second series of OLS regression (see Table VI) to identify which management challenges are affected by the interaction of the two SPM constructs. Note that all of the seven management challenges affected by the interaction term have negative numerical signs. In other words the above management challenges decrease when $X 1 * X 2$ increases from \pm 1 to +1 . Note that the interaction term $(X 1 * X 2)$ is \pm 1 for both mass service and service shops and +1 for service factory and professional service. Hence the seven interaction affects increase when one of the two SPM dimensions (labour intensity and customer contact/ customization) is changed from low-low (service factory) or high-high (professional service) to either low-high (service shop) or high-low (mass service). Interestingly, five of the seven statistically significant interactions are operational management challenges (capital decisions, fighting cost increases, technological advances, managing demand, and starting new operations).

Management Challenges Not Affected by Labour Intensity and Customer Contact/Customization

Only four management challenges (capital decisions, scheduling service delivery, scheduling workforce, and startup of new operations) were found to be related to both labour intensity and customer contact/customization. Of the rest, regression coefficients for six management challenges (Q10, Q13, Q17, Q18, Q20, Q22) were not found to be statistically significant for either customer contact/customization or labour intensity (see Figure 2). In other words, the managers in the four industries studied perceive the above management challenges as equally important. It should also be noted that two of the statistically non-significant management challenges (maintaining quality of service, and developing work and control methods) were rated to be among top-five by the managers.

\section{Proposed and Observed Management Challenges Relationships}

Only a small fraction (4 out of 22) of the management challenges relationships proposed by SPM are supported by the empirical analysis presented above (see Tables II and V). These results re-affirm the value of empirical data in supporting and/or falsifying theories (Flynn et al., 1990). Therefore controlled empirical studies should be conducted to test and verify SPM and other service management classification schemes.

\section{Conclusions, Limitations and Directions for Future Research}

Only a small fraction (4 out of 22) of the management challenges relationships proposed by SPM are supported by the empirical analysis presented above (see Tables II and V). These results re-affirm the value of empirical data in supporting and/or falsifying theories (Flynn et al., 1990). Therefore controlled empirical studies should be conducted to test and verify SPM and other service management classification schemes.

The results reveal the limitations of theoretical classification schemes. While theoretical typologies provide an important intuitive model of the basic differences among disparate 
groups, there are distinct limitations to their ability to capture all (or most) differences among service firms. Theoretical service typologies are to an extent similar to classifying individuals based on demographic characteristics. Such classifications do have intuitive appeal and can broadly provide general guidelines for groups but they do not take into account the individual differences among the group members. This is not to suggest that conceptual models and typologies are not valued. Instead, such typologies serve to focus our thoughts and provide an easily understood description of complex relationships. The role of empirical analysis is to test the extent to which such typologies fully represent reality and to suggest shortcomings, which lead to further research and refinement (Meredith et al., 1989). Toward that end, further research should seek to add to the current findings by examining additional quantitative measures in an effort to develop a more accurate classification model.

Therefore, we believe that the results presented in this study provide valuable information related to the management of service operations. Our role as business management researchers is to both understand the nature of "real life" operations and then suggest directions for improvement. Even though the current research was exploratory in nature it presented a better understanding of management issues related to various service industries. Building on these issues, future research should be directed towards identifying ways to address some of the important management issues identified here.

Even though this paper presents interesting results related to service management, the study contains a few limitations, which should be dealt with in future research projects. Here we discuss some of those limitations and provide directions for future research projects.

The current study implicitly assumes that SPM is a precise classification scheme and assumes that all fast food, automobile repair, retail, and legal services uniquely represent service factories, service shops, mass services, and professional services, respectively. For example, we did not measure customer contact/customization or labour intensity directly for each service organization. Future studies should collect additional data related to classification dimensions (customer contact, etc.) which allows the researchers to test if indeed the sampled firms belong in a certain SPM cell. We however, had intentionally kept the research design simple to increase response rate and because this study was exploratory in nature.

Another related issue involves the selection of service classification scheme for analysis. As mentioned earlier in the paper, service management literature contains a number of typologies and a few taxonomies. However there is none to limited empirical support for the proposed concepts. Therefore future research should be directed towards empirically testing/validating the proposed ideas.

With respect to the current study itself, a few issues are of concern. For example, since we developed the 22-item questionnaire based on SPM, it is possible that certain other important managerial challenges were ignored. Especially because SPM was developed during mid-1980s and the data for the current study was collected in 1996. Additionally, it is possible 
that managers in different service industries interpret each survey question differently because of their background (see Table III) and/or because of the nature of their service business.

As mentioned above, the current study contains several limitations, but at the same time provides empirical analysis of some important service management issues. We hope, that this study although exploratory in nature, would encourage others to reevaluate generally accepted concepts and hopefully motivate them to undertake empirical service management research projects.

\section{References}

Bowen, D.E. and Cummings, T.G. (1990), "Suppose we took service seriously", in Service Management Effectiveness, Jossey-Bass, New York, NY, pp. 1-4.

Chase, R.B. (1978), "Where does the customer fit in a service operation", Harvard Business Review, Vol. 56 No. 6, pp. 137-42.

Chase, R.B. (1981), "The customer contact approach to services: theoretical bases and practical extensions", Operations Research, Vol. 29 No. 4, pp. 698-700.

Chase, R.B. (1996), "The mall is my factory: reflections of a service junkie"', Production and Operations Management, Vol. 5 No. 4, pp. 298-308.

Chase, R.B. and Hayes, R.H. (1991), "Beefing-up operations in service firms", Sloan Management Review, Vol. 33 No. 1, pp. 15-26.

Fitzsimmons, J.A. and Fitzsimmons, M.J. (1997), Service Management: Operations, Strategy, and Information Technology, McGraw-Hill, New York, NY.

Flynn, B.B., Sakakibara, S., Schroeder, R.G., Bates, K.A. and Flynn, E.J. (1990), "'Empirical research methods in operations management", Journal of Operations Management, Vol. 9 No. 2, pp. 250-84.

Hayes, R.H. and Wheelwright, S.C. (1984), Restoring Our Competitive Edge: Competing Through Manufacturing, John Wiley, New York, NY.

Hill, T.P. (1977), "On goods and services", Review of Income and Wealth, Vol. 33, December.

Judd, R.C. (1964), "'The case for redefining services", Journal of Marketing, Vol. 28 No. 1.

Karmarkar, S. and Pitbladdo, R. (1995), "Service markets and competition", Journal of Operations Management, Vol. 12 No. 3, June, pp. 397-411.

Kellogg, D.L. and Chase, R.B (1995), “'Constructing an empirically derived measure for customer contact", Management Science, Vol. 41 No. 11, pp. 1734-49.

Kellogg, D.L. and Nie, W. (1995), "A framework for strategic service management", Journal of Operations Management, Vol. 13 No. 4, pp. 323-37. 
Kotler, P. (1980), Principles of Marketing, Prentice Hall, Englewood Cliffs, NJ.

Levitt, T. (1972), "Production-line approach to service", Harvard Business Review, Vol. 50 No. 4, pp. 41-52.

Levitt, T. (1976), "The industrialization of service", Harvard Business Review, Vol. 54 No. 5, pp. 63-74.

Linsky, A.S. (1976), "Stimulating responses to mailed questionnaires: a review", Public Opinion Quarterly, Vol. 39, pp. 82-101.

Lovelock, C.H. (1993), "Classifying services to gain strategic marketing insights", Journal of Marketing, Vol. 47 No. 3, pp. 9-20.

Meredith, J.R., Raturi, A., Amoako-Gyampah, K. and Kaplan, B. (1989), "Alternative research paradigms in operations", Journal of Operations Management, Vol. 8 No. 4, pp. 297-326.

Mersha, T. (1990), "Enhancing the customer contact model", Journal of Operations Management, Vol. 9 No. 3, pp. 391-405.

Rathmall, J.M. (1974), Marketing in the Service Sector, Winthrop, Cambridge, MA.

Roth, A.V., Chase, R.B. and Voss, C. (1997), Service in the US, Severn Trent plc.

Sasser Jr, E.E., Olsen, R.P. and Wyckoff, D.D. (1978), Management of Service Operations: Text and Cases, Allyn \& Bacon, Boston, MA.

Schmenner, R.W. (1986), "How can service businesses survive and prosper", Sloan Management Review, Vol. 27 No. 3, pp. 21-32.

Shostack, G.L. (1977), “'Breaking free from product marketing", Journal of Marketing, Vol. 41 No. 4.

Silvestro, R., Fitzgerald, L., Johnston, R. and Voss, C. (1992), 'Towards a classification of service processes", International Journal of Service Industry Management, Vol. 3 No. 3, pp. 6275.

Sullivan, R.S. (1981), "'The service sector: challenges and imperatives for research in operations management", Journal of Operations Management, Vol. 2 No. 4, pp. 211-14.

Swamidass, P.M. (1991), "Empirical science: new frontier in operations management research", Academy of Management Review, Vol. 16 No. 4, pp. 793-814.

Thomas, D.R.E. (1978), "Strategy is different in service businesses", Harvard Business Review, Vol. 56 No. 4, pp. 158-65.

US Department of Commerce (1994), Economic Classification Policy Committee, Issues Paper No. 6: Services Classifications. 
Verma, R. and Goodale, J.C. (1995), "Statistical power in operations management research", Journal of Operations Management, Vol. 13 No. 2, pp. 139-52.

Voss, C. and Johnston, R. (1995), Service in Britain: How Do We Measure Up?, Severn Trent PIc.

Wemmerlov, U. (1990), "A taxonomy for service processes and its implications for system design", The International Journal of Service Industry Management, Vol. 1 No. 3, pp. 1327. 